\title{
TAJEMNICA KRZYŻA W UJĘCIU HANSA URSA VON BALTHASARA
}

Tym, co najbardziej oryginalne w teologii Hansa Ursa von Balthasara, jest jej trylogiczny układ, a więc podział na estetykę teologiczna, teodramatykę i teologikę. Pierwsza część teologicznej trylogii, skoncentrowana na pięknie estetyka teologiczna (Herrlichkeit), ukazuje Chrystusa jako centrum objawienia chwały Boga; druga jej część, skupiona na dobru teodramatyka (Theodramatik), mówi o działaniu Boga w zbawczym dramacie oraz współpracy człowieka z Bogiem, stawiając w centrum misję Chrystusa; trzecia wreszcie, skonstruowana wokół prawdy teologika (Theologik), wyjaśnia znaczenie wejścia Boga, w szczególności zaś odwiecznego Logosu, w granice skończonej stworzonej logiki ${ }^{1}$. Tajemnica krzyża odgrywa w twórczości bazylejskiego teologa kluczową rolę. Zgodnie z układem jego teologicznej trylogii, nasza refleksja nad tajemnicą krzyża podzielona zostanie na trzy części poświęcone odpowiednio tajemnicy mocy Bożej w dramacie

* Ks. prof. dr hab. Marek Pyc - kierownik Zakładu Teologii Dogmatycznej na Wydziale Teologicznym im. Adama Mickiewicza w Poznaniu.

${ }^{1}$ Por. H. U. von Balthasar, Wprowadzenie do ksiażki: G. Marchesi, La cristologia di Hans Urs von Balthasar, VIII. Szersze opracowanie tej kwestii: M. Pyc, Chrystus Piękno - Dobro - Prawda. Chrystologia Hansa Ursa von Balthasara w jej trylogicznym uktadzie, Poznań 2002. 
krzyża (p. 1), tajemnicy mądrości Bożej w „głupstwie” krzyża (p. 2) oraz tajemnicy Bożej chwały w "zgorszeniu” bądź też „skandalu” krzyża (p. 3).

\section{MOC BOŻA W DRAMACIE KRZYŻA}

Historię zbawienia określa Hans Urs von Balthasar mianem zbawczego dramatu. Fakt, iż Bóg stwarza człowieka wolnym, nieuchronnie doprowadza do konfrontacji pomiędzy nieskończoną wolnością boską i skończoną wolnością ludzką ${ }^{2}$. Historia zbawienia aktualizuje się jako dramat rozgrywający się między Bogiem i człowiekiem, który otrzymanej wolności nadużył. Odtąd w dziejach świata toczy się dramatyczna batalia o zwycięstwo dobra nad złem. Uznany za znak całkowicie pozbawiony mocy, krzyż zdaje się świadczyć o niemocy, słabości i bezsilności Boga. Paradoksalnie jednak właśnie w ten sposób w krzyżu zamanifestowana zostaje niepojęta moc Boża.

Zbawczy dramat jest $\mathrm{w}$ istocie dramatem w Jezusie Chrystusie. To właśnie On, wcielony Syn Boży, jest definitywnym słowem Boga skierowanym do grzesznego świata. On też stanowi warunek zaistnienia dramatu w ogóle, ogarniając bieg dziejów świata, które od momentu upadku człowieka nieuchronnie zmierzały ku tragicznemu finałowi. Gdy odwieczne Słowo staje się ciałem, dochodzi do dramatu w znaczeniu absolutnym. W Nim zostaje otwarta dramatyczna przestrzeń. W tym historiozbawczym dramacie jest On zaangażowany jako protagonista (Hauptfigur). Tragedię świata, pozbawionego nadziei na jakiekolwiek pozytywne jej rozwiązanie, przemienia On w dramatyczną, ostatecznie zwycięską historię zbawienia ${ }^{3}$.

Kluczowym momentem w zbawczej misji Jezusa Chrystusa jest Jego dramatyczna śmierć na krzyżu. Tajemnicę krzyża uznaje bazylejski teolog za centrum i szczyt, a zarazem punkt zwrotny w historiozbawczym dramacie. Teologia nowotestamentalna ukazuje krzyż jako wydarzenie, ku któremu zmierzała cała poprzedzająca je historia zbawienia i które ma zarazem rozstrzygające znaczenie dla całej chrześcijańskiej przyszłości

2 Por. H. U. von Balthasar, O moim dziele, Kraków 2004, 69.

3 Por. tenże, Theodramatik. Band II: Die Personen des Spiels. Teil 1: Der Mensch in Gott, Einsiedeln 1976, 24.111 (odtąd skrót: TD II/1); tenże, Theodramatik. Band II: Die Personen des Spiels. Teil 2: Die Personen in Christus, Einsiedeln 1978, 29.37 (odtąd skrót: TD II/2).

4 TD II/2, 15.44.46. Balthasar, podkreślając rozstrzygające znaczenie, a zarazem 
Jedną z najbardziej charakterystycznych cech znamionujących dramatyczne życie i misję Jezusa jest dla Balthasara janowy motyw "godziny", która coraz wyraźniej jawi się jako godzina krzyża. Jego ziemska misja stanowi swoiste preludium do decydującego dzieła, jakie dokona się na krzyżu. Także Jego nacechowana radykalizmem nauka staje się zrozumiała jedynie $\mathrm{w}$ perspektywie krzyża, ku któremu zmierza całe Jego życie. Krzyż nie stanowi odizolowanego wydarzenia, lecz moment, ku któremu zorientowana jest Jego zbawcza misja. On konsekwentnie podąża ku Jerozolimie, gdzie na krzyżu ma dopełnić się ofiara Jego życia 5 . Śmierć Jezusa na krzyżu stanowi interpretacje całej Jego egzystencji. Jest ona kluczem do zrozumienia Jego życia, które w żadnym innym momencie nie zostaje tak dogłębnie wyjaśnione, jak właśnie z perspektywy śmierci. Uzasadnieniem radykalizmu Jego nauczania, stawianych wymagań i spełnianych czynów jest, w przekonaniu naszego autora, perspektywa Jego zupełnie wyjątkowej śmierci. Zawarte w słowach i czynach roszczenie Jezusa prowokuje Jego śmierć, w pewnym sensie ją „zwabia”. On ma prawo wypowiadać tak niesłychane słowa i dokonywać takich dzieł jedynie pod warunkiem, że już z góry znajdują one swoje pokrycie w złożonym przez Niego w momencie śmierci doskonałym świadectwie $(1 \operatorname{Tm} 6,12)^{6}$.

Ofiarnicza śmierć wcielonego Syna Bożego nie jest efektem jakiegoś genialnego improwizowanego zrywu, lecz wyrazem wiernej realizacji zleconej Mu przez Ojca misji. Ojciec „nawet własnego Syna nie oszczędził,

dramatyczność śmierci Jezusa, określa wydarzenie krzyża jako „der Ernstfall”: Cordula oder der Ernstfall, Einsiedeln 1966, 7-45. Por. E. Giammancheri, Presentazione, w: H. Urs von Balthasar, Cordula ovverosia il caso serio, Brescia 1968, 7-14; X. Léon-Dufour, Jésus face à la mort menaçante, „Nouvelle Revue Théologique” 110 (1978) 6, 802-821; K. Lehmann, "Er wurde für uns gekreuzigt». Eine Skizze zur Neubesinnung in der Soteriologie, „Theologische Quartalschrift” 162 (1982) 4, 298-317.

${ }^{5}$ Por. H. U. von Balthasar, Glaubhaft ist nur Liebe, Einsiedeln 1963, 55-57 (odtąd skrót: GL); tenże, Mysterium Paschale, w: J. Feiner, M. Löhrer (red.), Mysterium Salutis. Grundriss heilsgeschichtlicher Dogmatik. Band III/2: Das Christusereignis, Einsiedeln/Zürich/ Köln 1969, 138.185 (odtąd skrót: MP); tenże, Herrlichkeit. Eine theologische Ästhetik. Band III/2: Theologie. Teil II: Neuer Bund, Einsiedeln 1969, 187 (odtąd skrót: H III/2/2); Tenże, Der dreifache Kranz. Das Heil der Welt im Mariengebet, Einsiedeln 1977, 45 (odtąd skrót: DK). Por. także: J. Galot, Il turbamento del Cristo di fronte all'ora della passione, „La Civiltà Cattolica" 147/1 (1996) 446-459.

${ }^{6}$ Por. H. U. von Balthasar, Theodramatik. Band III: Die Handlung, Einsiedeln 1980, 460-463 (odtąd skrót: TD III); tenże, Theodramatik. Band IV: Das Endspiel, Einsiedeln 1983, 296 (odtąd skrót: TD IV). Por. także: H. Schürmann, Jesu ureigener Tod, Freiburg im Breisgau 1975. 
ale Go za nas wszystkich wydał” (Rz 8, 32). „On to zesłał swego Syna $\mathrm{w}$ ciele podobnym do ciała grzesznego i dla usunięcia grzechu wydał w tym ciele wyrok potępiający grzech" (Rz 8, 3). To, że Ojciec wydaje swojego Syna, należy, zdaniem Balthasara, do najbardziej niesłychanych stwierdzeń Nowego Testamentu. Z wydaniem ze strony Boga współgra zgoda Jezusa na bycie wydanym, będąca aktem posłuszeństwa Ojcu: „Mam moc oddać moje życie... Taki nakaz otrzymałem od mojego Ojca” (J 10, 18-19) ${ }^{7}$.

Zbawczy dramat dochodzi do szczytu właśnie na krzyżu, kiedy to Baranek Boży zostaje obarczony grzechem świata. W Nim skoncentrowany zostaje wszelki grzech, który sprzeciwia się Bogu, wzbudzając Jego gniew. Takie właśnie znaczenie mają dla bazylejskiego teologa słowa, iż „Bóg uczynił Go grzechem” (2 Kor 5, 21). Dla wyjaśnienia sensu tajemnicy krzyża nie wystarczy mówić o solidarności z ludźmi podlegającymi przekleństwu śmierci. Jezus nie jest jednym spośród wielu dźwigających wspólny ludzki los, lecz jedynym, który dźwignął w zastępstwie za grzeszników grzech świata. Stało się to możliwe dzięki Jego niepowtarzalnej synowskiej relacji do Ojca. Dla realizacji tego zastępczego dzieła konieczne było, by stał się On prawdziwym człowiekiem, gdyż tylko pod tym warunkiem był On w stanie wziąć na siebie grzech świata w zastępstwie za grzeszników, musiał On być jednak zarazem Bogiem, gdyż żaden człowiek nie może w pełni zająć miejsca drugiego bez naruszenia jego godności jako wolnej i odpowiedzialnej za siebie osoby. Tajemnica wcielenia jawi się zatem jako warunek możliwości wzięcia na siebie grzechu świata przez Jezusa Chrystusa,. Tylko dlatego, że jest On odwiecznym Synem Bożym i zarazem człowiekiem, może podjąć się realizacji tego zadania. Jedynie pod tym warunkiem może doświadczyć w cierpieniu całej otchłani ludzkiego „nie” wypowiedzianego przeciwko miłości Boga8. Podczas gdy zostaje obarczony grzechem świata, Jego miłość posuwa się

${ }^{7}$ MP, 200-202; H III/2/2, 208. Nasz autor nawiązuje tu do myśli W. Popkesa, który zwraca uwagę, iż pełny sens słowa "wydanie“ nie może być tu zwyczajnie osłabiony pojęciem „posłania” czy też „daru”. Tu zdarzyło się to, co zostało oszczędzone Abrahamowi w relacji do syna Izaaka. Chrystus w pełni świadomie został pozostawiony przeznaczeniu na śmierć, niszczącym mocom ciemności. Por. W. Popkes, Christus traditus. Eine Untersuchung zum Begriff der Dahingabe im Neuen Testament, "Abhandlungen zur Theologie des Alten und Neuen Testaments" 49 (1967) 286-287.

${ }^{8}$ MP, 223-224; H III/2/2, 196-197; H. U. von Balthasar, Pneuma und Institution. Skizzen zur Theologie IV, Einsiedeln 1974, 402 (odtąd skrót: PI). Por. P. Galtier, "Obéissant jusqu'à la mort”, „Revue d'ascétique et mystique” 1 (1920) 113-145. 
tak daleko, że nie odróżnia On już siebie samego i swojego własnego losu od losu grzeszników, doświadczając lęku i trwogi, na które oni zasłużyli. Na krzyżu każdy człowiek, bez względu na to kim jest i do jakiego stopnia się $\mathrm{w}$ życiu zagubił, ogarnięty zostaje miłością Boga. Za każdym bez wyjątku stoi niosąca odkupienie i pojednanie miłość Ukrzyżowanego. Dlatego też ludzie małoduszni, niezdolni do miłości, którzy zasklepili się w sobie pogrążeni w nocy egoizmu i pychy, są dla umierającego na krzyżu Chrystusa najbliższymi braćmi, bo też za nich musiał On najwięcej wycierpieć ${ }^{9}$.

Na krzyżu ma miejsce gwałtowne zanurzenie w otchtań lęku. Napełnia ona Jezusa "drżeniem i odczuwaniem trwogi" (Mk 14, 33). Jest to lęk, który cierpi On zastępczo za każdego grzesznika i za każdy grzech, stając w obliczu Boga, absolutnej sprawiedliwości. On jest w pełni człowiekiem obarczonym grzechem niemożliwym do tolerowania przez Boga. Na krzyżu Jezus doświadcza obrazu Boga sprawiedliwego, bo takim właśnie jawi się Mu na krzyżu Ojciec widziany i doświadczany przez pryzmat serc i oczu grzeszników. Przyjmuje na siebie lęk, który musiałby przeżyć grzesznik stając przed sądem Bożym skazującym na potępienie. A jednak jest to, jak zauważa nasz autor, przede wszystkim lęk Boga w ludzkiej postaci o świat, który obecnie znajduje się $\mathrm{w}$ stanie całkowitego zagubienia i może ulec zatraceniu. Właśnie na tej drodze Chrystus tłumaczy na język ludzki coś niepojętego, a mianowicie zatroskanie Boga o swoje stworzenie, któremu zagraża zguba. Jego lęk jest w pełnym tego słowa znaczeniu lękiem absolutnym, nieskończenie przewyższającym wszelki inny i każdemu innemu towarzyszącym ${ }^{10}$.

Jezus przeżywa śmierć na krzyżu w dogłębnej wspólnocie z grzesznikami. Gdy przyjmuje na siebie grzech świata, doświadcza najciemniejszej nocy utraty Boga, a więc stanu bycia opuszczonym przez Ojca (2 Kor 5, 14.21; Ga 3, 13; Ef 2, 14-16). W skrajnym osamotnieniu umiera z pytaniem skierowanym do nieobecnego Boga, dlaczego Go opuścił ${ }^{11}$. Doświadczenie całkowitego opuszczenia i oddalenia od Boga, na które zasługuje sobie grzesznik, jest dla Niego możliwe, jako że dla nas stał się On człowiekiem. Będąc "ucieleśnieniem grzechu”, który dźwiga w sobie, nie może

\footnotetext{
${ }^{9}$ MP, 197; H. U. von Balthasar, Wer ist ein Christ?, Einsiedeln 1983, 97.

${ }^{10}$ Por. H. U. von Balthasar, Der Christ und die Angst, Einsiedeln 1976, 37-38 (odtąd skrót: CA); H III/2/2, 206-207; DK, 45-46.

${ }^{11}$ Por. H. U. von Balthasar, Credo. Meditationen zum Apostolischen Glaubensbekenntnis, Freiburg im Breisgau 1989, 45-46.
} 
znaleźć w Ojcu żadnego oparcia, przyjął bowiem na siebie to, co Bóg musi bezwzględnie odrzucić. W tej ekstremalnej próbie nie odczuwa już Jego bliskości, ponieważ teraz w zastępstwie za grzeszników doświadcza, co znaczy stracić wszelki kontakt z Bogiem. Jedynie odwieczny Syn może w pełni przeżyć dramat bycia opuszczonym przez Ojca, bo tylko On wie, kim jest Ojciec i co oznacza Jego bliskość i miłość. Tylko On, którego pokarmem jest czynienie woli Ojca, może mieć świadomość, co oznacza brak tego pokarmu, i pragnąć (J 19, 28). Nieskończenie głębiej niż jakiekolwiek inne stworzenie, doświadcza On opuszczenia i umierania w oddaleniu od Boga oraz ciemności wiecznej śmierci, będących skutkiem ludzkiego grzechu. Balthasar przestrzega jednak przed pochopnym wyciąganiem fałszywych wniosków. Nie wolno twierdzić, jakoby Jezus został ukarany przez Boga w miejsce grzeszników, albo też czuł się przez Boga potępiony i umieszczony w piekle. To, co wyobrażamy sobie jako piekło, złączone jest z nienawiścią wobec Boga i bezsensem byłoby przypisywanie jej Ukrzyżowanemu. Jako Syna pochodzącego z ojcowskiego źródła przenika Go nieskończone pragnienie bliskości Ojca, który stał się niedostępny. Płonie ono w Nim na podobieństwo wiecznego ognia podsycanego i intensyfikowanego teraz przez Ducha. To właśnie Duch Święty jednoczy Go z Ojcem, wzmagając do ostatecznych granic ich wzajemną miłość ${ }^{12}$.

Cena pojednania w śmierci na krzyżu uświadamia nam, że wizje Bożego gniewu $(\operatorname{Rz} 5$, 9) i karzacego sądu $(\operatorname{Rz} 8$, 3) jako reakcji na ludzki grzech są czymś ekstremalnie realnym i niemożliwym do pominięcia. W Ukrzyżowanym złożona nam została ostateczna oferta miłości. Bóg nie mógł dla nas uczynić więcej nad wydanie za nas swojego Syna. Poza łaską wysłużoną na krzyżu, zbawienie nie jest możliwe. Miłością nie można gardzić ani jej bezkarnie odrzucać, nie podpadając pod sąd. Krzyż okazuje się być sądem samej miłości. Ojciec, który daje swego Syna jako najwyższy dar swej miłości, stoi za swoją ofertą jako sędzia. Jeżeli ktoś nie pozwala się obdarować łaską płynącą z krzyża, pozostaje dla niego już tylko sąd. Gniew Boży oznacza kategoryczne „nie” Boga wypowiedziane wobec grzesznej nieprawości ${ }^{13}$. Bazylejski teolog odkrywa w nim

12 Por. H. U. von Balthasar, Kennt uns Jesus? Kennen wir Ihn?, Freiburg im Breisgau 1980, 42-45 (odtąd skrót: KJK); tenże, Neue Klarstellungen, Einsiedeln 1979, 68; DK, 64-66.

${ }^{13}$ H III/2/2, 189-191; KJK, 94-100; H. U. von Balthasar, Das betrachtende Gebet, Einsiedeln 1976, 208-209 (odtąd skrót: BG). 
drugie oblicze autentycznej miłości Boga w reakcji na zło. Nie odpuszcza On grzechów bez zadośćuczynienia. Czysta amnestia oznaczałaby w tym wypadku ignorowanie zła, czy wręcz przyznanie mu racji bytu. Bóg nie pozostaje obojętny wobec grzechu i nie toleruje niesprawiedliwości, ponieważ na serio traktuje człowieka, partnera przymierza. Kiedy zaś ten zawodzi, Bóg sam zabezpiecza pełną realizację swego zbawczego zamysłu. Przyjmując ludzką naturę, przechodzi na stronę zagubionego człowieka. Nie eliminuje niesprawiedliwości połowicznie, lecz ogarnia ją od samych podstaw i bezkompromisowo odrzuca. Takiego dzieła może się podjąć, w przekonaniu Balthasara, jedynie umiłowany, absolutnie bezgrzeszny Syn, który w czasie męki doświadcza gniewu Boga. Wyłącznie On jest zdolny ostatecznie położyć kres temu straszliwemu gniewowi ${ }^{14}$.

W krzyżu bazylejski teolog odkrywa ostatecznie niewiarygodnq moc Ojca, który, pozornie nieobecny i bezsilny, towarzyszy cierpiącemu i umierającemu Synowi. Syn oddaje siebie w niedostrzegalne teraz ręce Ojca, który Go posłał i współuczestniczy w Jego darze ${ }^{15}$. W godzinie krzyża nieposłuszeństwo grzechu, rozumiane jako suma całego grzesznego buntu przeciw Bogu w dziejach świata, okazuje się czymś skończonym $\mathrm{w}$ porównaniu z niewyczerpanym posłuszeństwem Syna Bożego. To właśnie Jego uległość ogarnia grzech od samych podstaw, odbierając mu rację bytu ${ }^{16}$. Dramat krzyża okazuje się ostatecznie zwycięski. Jest on objawieniem tajemniczej mocy Bożej, której owocem będzie wskrzeszenie Jezusa z martwych.

\section{MĄDROŚĆ BOŻA W „GŁUPSTWIE" KRZYŻA}

Całość refleksji Hansa Ursa von Balthasara nad misterium krzyża przenika motyw ukrycia i tajemnicy. Bazylejski teolog zdaje sobie sprawę, że jest czymś ekstremalnie trudnym zrozumieć paradoks zawarty w śmierci Jezusa na krzyżu. Logika krzyża jest radykalnie inna od logiki tego świata. Krzyż pozostaje dla świata czymś skandalicznym i gorszącym. Umierający na krzyżu jest dla żydów zgorszeniem, obrazą i skandalem, a dla pogan głupstwem (1 Kor 1, 23) i sam prowokuje, by Go odrzucić. Pozostając pozornie głupstwem, krzyż objawia tajemniczq ukryta

${ }^{14}$ MP, 208-210.225.

${ }_{15}$ TD IV, 297-298.306. Por. A. von Speyr, Passion von innen, Einsiedeln 1981, 88.

${ }^{16} \mathrm{PI}, 408$; por. $\mathrm{H} \mathrm{III/2/2,} 207$. 
mądrość Boga i Jego zbawczego zamystu $(2,7)$. „To bowiem, co jest głupstwem u Boga, przewyższa mądrością ludzi, a to, co jest słabe u Boga, przewyższa mocą ludzi" $(1,25)$. Dlatego też skandalu krzyżowej śmierci nie wolno wyeliminować, aby krzyż nie został zniweczony $(1,17)$. Będąc „kamieniem obrazy i skałą zgorszenia” (Rz 9, 33; 1 P 2, 6-8), Ukrzyżowany staje się kamieniem węgielnym (Ps 118, 22). Wykraczając ponad wszelką ludzką logikę, śmierć Jezusa jest w swej ostatecznej niemocy czynem i objawieniem mądrości Boga przewyższającej mądrość ludzką ${ }^{17}$.

Dla zrozumienia logiki krzyża konieczna okazuje się interpretacja jego tajemnicy przez Ducha Świętego. Odejściu Jezusa w śmierci na krzyżu towarzyszy obietnica przyjścia interpretującego prawdę Ducha: „Pożyteczne jest dla was moje odejście. Bo jeżeli nie odejdę, Pocieszyciel nie przyjdzie do was. A jeżeli odejdę, poślę Go do was" (J 16, 7). Konieczność Jego odejścia wiąże Balthasar z faktem, że objawiona przez wcielone Słowo Boże prawda będzie mogła się zamanifestować $\mathrm{w}$ całej swej pełni dopiero wówczas, gdy zostanie wypowiedziana aż do samego końca $w$ śmierci na krzyżu $i$ zmartwychwstaniu. Tak urzeczywistniona pełnia prawdy będzie możliwa do zrozumienia jedynie dzięki interpretacji Ducha Świętego. Duch przypomni i wyjaśni wszystko, co zostało powiedziane i dokonane wcześniej przez Chrystusa (J 16, 29). Dzięki Duchowi Prawdy, który doprowadzi ich do pełni prawdy $(\mathrm{J} 16,13)$, uczniowie będą w stanie głębiej zrozumieć z paschalnej perspektywy sens tajemnicy krzyża. To, co dotychczas wydawało się im niełatwym $\mathrm{w}$ interpretacji przemawianiem $\mathrm{w}$ przypowieściach, w krzyżu zostaje wypowiedziane z całą otwartością i okazuje się możliwe do zrozumienia. Krzyż, który jawił się dotąd jako głupstwo, zostaje zinterpretowany przez Ducha jako szczytowa Boża mądrość ${ }^{18}$. Właśnie na bazie krzyża Duch Święty jako adwokat i obrońca Chrystusa przeprowadzi wobec świata proces $\mathrm{W}$ sprawie Jego niewinności ${ }^{19}$.

Duch Święty wyjaśnia sens i logikę tajemnicy wcielenia, a więc prawdy o Synu Bożym, który stał się człowiekiem i umarł na krzyżu dla

${ }^{17} \mathrm{H} \mathrm{III/2/2,} \mathrm{204-206;} \mathrm{MP,} \mathrm{138.161;} \mathrm{H.} \mathrm{U.} \mathrm{von} \mathrm{Balthasar,} \mathrm{Glaubhaft} \mathrm{ist} \mathrm{nur} \mathrm{Liebe,} \mathrm{Ein-}$ siedeln 1963, 56 (odtąd skrót: GL). Por. J. Ratzinger, La sinfonia della croce: «La conoscenza di Dio che rifulge sul volto di Cristo», „Antonianum” 55 (1980)1/2, 280-286; F.-J. Steinmetz, Die Weisheit und das Kreuz, "Geist und Leben” 72 (1999) 2, 112-126; A. M. Sicari, La «stoltezza della Croce», „Rivista Internazionale di Teologia e Cultura "Communio»" 24 (1996) 1, 18-27; S. Cipriani, «Sapientia crucis» e sapienza «umana» in Paolo, „Rivista Biblica” 36 (1988) 3, 343-361.

${ }^{18}$ Por. H. U. von Balthasar, Theologik. Band III: Der Geist der Wahrheit, Einsiedeln 1987, 64.74-75 (odtąd skrót: TL III).

${ }^{19} \mathrm{MP}, 208$. 
naszego zbawienia. Bóg wybrał niemożliwą do przewidzenia dla świata drogę odkupienia poprzez ciało. Przyjęcie we wcieleniu ciała grzechu oznacza, że wcielony Syn Boży solidaryzuje się i wchodzi w jedność z grzesznikami, biorąc na siebie balast ludzkich grzechów. Dokonuje odkupienia świata trwając nie tylko w jedności z Ojcem, lecz - dzięki przyjęciu człowieczeństwa - także w zjednoczeniu z ludźmi. Stąd też na krzyżu może dźwignąć w sobie wszystkich grzeszników. Na pierwszy rzut oka, pisze bazylejski teolog, wszystko wydaje się sprzecznością. A jednak właśnie na tej zasadzie, gdy będąc bezgrzesznym, przyjmuje On na siebie wszelką nieczystość ludzkiego grzechu, staje się Odkupicielem. W ten sposób dokonuje dzieła odkupienia nie eliminując życia człowieka w ciele, lecz na drodze jego dogłębnej odnowy i przemiany ${ }^{20}$.

Duch wyjaśnia znaczenie postuszeństwa wcielonego Syna Bożego, który ogołocił samego siebie, przyjąwszy postać sługi, stając się posłusznym aż do śmierci, i to śmierci na krzyżu (Flp 2, 7-8). Balthasar podkreśla, że okazane w momencie śmierci posłuszeństwo już od wcielenia przenika i determinuje całą Jego ziemską egzystencję. Krzyż nie jest efektem przypadkowego zbiegu okoliczności. Chrystus nie próbuje niczego dokonać na własną rękę, lecz godzinę śmierci zawierza Ojcu. Nie obarcza sam siebie winą świata, lecz przyzwala, by została ona nałożona na Niego zgodnie z wolą Ojca. Może jej stawić czoła jedynie w bezwzględnej uległości Ojcu i Jego zamiarom. Właśnie dlatego, że, będąc odwiecznym Synem Bożym, w posłuszeństwie przyjmuje poddaną prawu umierania ludzką naturę, Jego śmierć może odnieść zwycięstwo nad ciążącym na ludzkości śmiertelnym przeznaczeniem. Jego posłuszeństwo stanowi przeciwwagę grzechu nieposłuszeństwa. On włącza śmierć grzesznika w swoją własną śmierć, radykalnie ją przewartościowując. Ponieważ Jego śmierć jest wypełnieniem z uległością woli Ojca, nieomylnie prowadzi $\mathrm{ku} z$ martwychwstaniu ${ }^{21}$. Niewyobrażalna dla świata cudowna wymiana (admirabile commercium), tak jak ją rozumieli Ojcowie, nie bazuje na czy-

${ }^{20}$ Por. H. U. von Balthasar, Theologik. Band II: Wahrheit Gottes, Einsiedeln 1985, 294-296 (odtąd skrót: TL II). Por. także: A von Speyr, Erde und Himmel, Einsiedeln 1975-1976: II, 157.305; III, 286-287; B. Stubenrauch, Die Menschheit Jesu als Schlüssel zur Heilsbedeutsamkeit des Kreuzes, „Münchener Theologische Zeitschrift” 46 (1995) 3, 345-354.

${ }^{21}$ TD III, 460-461.464; TD IV, 296-297. 311. Por. A. von Speyr, Das Geheimnis des Todes, Einsiedeln 1953, 66; C. Basevi, Estudio literario y teológico del himno cristológico de la Epístola a los Filipenses (Phil 2,6-11), "Scripta Theologica" 30 (1998) 2, 439-472; G. Iammarrone, La figura di Gesü «Servo» e il tema del «servizio» nella cristologia sistematica contemporanea, „Miscellanea Francescana” 97 (1997) 3/4, 449-489. 
sto formalnej wymianie grzechu i łaski, lecz na motywowanym miłością posłuszeństwie Ojcu aż do śmierci na krzyżu, którym przezwyciężył On bunt pierwszego Adama22.

Duch, który „przenika głębokości Boga samego” (1 Kor 2, 10), odsłania przed nami trynitarna logikę miłości. Poznajemy Ojca, który „tak umiłował świat, że dał swojego Jednorodzonego Syna, aby każdy, kto w Niego wierzy, miał życie wieczne" (J 3, 16). W równej mierze jest nam dane poznać Syna, który bierze na siebie sprzeczność grzechu, jego kłamstwo i nielogiczność, i przezwycięża go od samych podstaw. Trynitarna logika miłości sprawia, że na krzyżu grzech zostaje definitywnie potępiony, a zbawczy dramat okazuje się ostatecznie zwycięski. W darze z Syna aż po śmierć na krzyżu zawarte jest już bezwzględnie wszystko (Rz 8, 32), tak że poza nim Ojciec nie ma już nic więcej do ofiarowania światu (Hbr 6, 4-8; 10, 26). Dzięki obecności i mocy wiecznego Ducha krzyżowa ofiara ma nieskończoną i nieprzemijającą wartość23.

\section{CHWAŁA BOŻA W „SKANDALU” KRZYŻA}

Hans Urs von Balthasar dostrzega nierozerwalną więź między teologią krzyża i teologią chwały. Pojęcie chwaty (Herrlichkeit) odniesione do Boga oznacza Jego absolutny majestat, wspaniałość Jego bezinteresownej miłości, jaka manifestuje się wobec świata. Jest ona obecna jest zarówno w stworzeniu, jak i w historii zbawienia, a swoją pełnię osiąga w Chrystusie. W Nim Bóg objawia nam siebie, by opromienić nas wspaniałością boskiej miłości, a czyni to z absolutną bezinteresownościa (Interesselosigkeit), która jest wspólna cecha miłości i piękna ${ }^{24}$. Szczególnym miejscem obecności chwały Boga jest misterium paschalne. Choć zajaśnieje ona w całej pełni dopiero w zmartwychwstaniu, jest już obecna w wydarzeniu krzyża $a^{25}$. Stąd też śmierć Jezusa na krzyżu uznaje nasz autor za wyjątkowe miejsce promieniowania Bożej chwały.

22 TL II, 314.

${ }^{23}$ TL II, 137-138.297-298; TL III, 66.158-160. Por. V. Battaglia, Cristologia dello Spirito e teologia trinitaria della croce, „La Sapienza della Croce” 2 (1987) 2, 113-123.

${ }^{24} \mathrm{H}$ III/2/2, 223-224; H. U. von Balthasar, Herrlichkeit. Eine theologische Ästhetik. Band I: Schau der Gestalt, Einsiedeln 1961, 65 (odtąd skrót: H I); tenże, Rechenschaft 1965, Einsiedeln 1965, 27-28.

${ }^{25}$ MP, 212. Por. T. Vogel, Die Herrlichkeit des Gekreuzigten. Eine theologische Erinnerung an Hans Urs von Balthasar, "Theologische Literaturzeitung” 116 (1991) 6, 401-416; L. Malevez, La gloire de la Croix, „Nouvelle Revue Théologique” 95 (1973) 10, 1057-1089. 
Myśl Balthasara jest szczególnie bliska chrystologii św. Jana, dla którego wydarzenie krzyża stanowi epifanię chwaty Boga $a^{26}$. Poprzedzające godzinę paschalną życie Jezusa uznaje bazylejski teolog za zapoczątkowanie i zadatek wywyższenia i uwielbienia miłości Boga $\mathrm{w}$ ofierze krzyża. Męka i śmierć, wkroczenie światła w ciemności, uniżenie się i posunięte do ekstremum zstąpienie $\mathrm{z}$ motywu miłości są zbawczymi wydarzeniami odsłaniającym chwałę Boga. Za św. Janem nasz autor uznaje podwyższenie na krzyżu i uwielbienie w zmartwychwstaniu za jedno niepodzielne wydarzenie. Już sam krzyż, pozostający w ścisłej łączności ze zmartwychwstaniem, jest tajemnicą uwielbienia. Dlatego też śmierć na krzyżu widziana jest przez niego jako "godzina”, w której Ojciec czyni swego Syna manifestacją boskiej chwały. Znaczy to, że już w śmierci na krzyżu ma miejsce uwielbienie wcielonego Syna Bożego. I choć Jego zmartwychwstanie stanowi jeszcze jedno dzieło Ojca, jest ono postulowane jako akt sprawiedliwości przez tajemnicę krzyża do tego stopnia, że właściwie jest już w nim zawarte. W janowej wizji śmierć na krzyżu otoczona jest promieniującą chwałą, a krzyż uznany zostaje za tajemnicę podwyższenia: „Potrzeba, by wywyższono Syna Człowieczego, aby każdy, kto w Niego wierzy, miał życie wieczne” (J 3, 14). „A Ja, gdy zostanę nad ziemię wywyższony, przyciągnę wszystkich do siebie. To powiedział zaznaczając, jaką śmiercią miał umrzeć" (J 12, 32-33). Zmartwychwstały Pan to zarazem ten, który został ukrzyżowany. Chwała, która zajaśniała w śmierci na krzyżu, pozostanie już na zawsze aktualną wspaniatościq ukrzyżowanej Miłości (Herrlichkeit)27. Przebity włócznią, podwyższony na krzyżu Chrystus jest ostateczną ikoną boskiej chwały (J 19, 32). On jest kimś więcej niż "Ecce Homo". Jest On "Ecce Deus", jako definitywne objawienie majestatu chwały Boga ${ }^{28}$.

Stając się milczącym barankiem prowadzonym na zabicie (Jr 11, 19; Iz 53, 7), Chrystus w postawie ekstremalnego synowskiego posłuszeństwa doświadcza bezdennej nocy krzyża. Właśnie to bezgraniczne postuszeństwo Ojcu aż do śmierci na krzyżu postuluje uwielbienie Syna ze strony Ojca,

${ }^{26} \mathrm{H}$ III/2/2, 295. Por. W. Thüsing, Die Erhöhung und Verherrlichung Jesu im Johannesevangelium, Münster 1960, 133nn; J. Blank, Krisis. Untersuchung zur johanneischen Christologie, Freiburg 1964, 289nn.

${ }^{27}$ MP, 210-211; H III/2/2, 211. 352-353; DK, 68. Por. R. Tremblay, «La gloria delle glorie è la croce», "Vivens Homo" 10 (1999) 2, 337-346; P. Létourneau, La gloire de Jésus: Gloire et glorification dans le IV-e Évangile, „Laval Théologique et Philosophique” 51 (1995) 3, 551-572.

${ }^{28}$ MP, 216. Por. V. Battaglia, Gesů Crocifisso, icona della gloria e dell'amore di Dio. Un saggio di cristologia staurologico-agapica, „Ricerche Teologiche” 3 (1992) 1, 7-32. 
i już uprzednio je zapowiada: „Jeżeli Bóg został w Nim otoczony chwałą, to i Bóg Go otoczy chwałą w sobie samym, i to zaraz Go chwałą otoczy" (J 13, 32). W zdaniu się całkowicie na Ojca, uległości i przyzwoleniu na to, by przez Niego zrealizowały się zbawcze ojcowskie plany, jaśnieje chwała Boga ${ }^{29}$. W posłuszeństwie Ojcu aż do śmierci na krzyżu objawia On Boga wspaniałego w swojej miłości.

W krzyżu objawia się jaśniejąca chwałą odwieczna miłość Boga, która zstąpiła na ziemię, aby dokonać dzieła naszego usprawiedliwienia. W wizji św. Jana całe życie Jezusa jest w istocie miłością, wyrażającą się w poświęceniu samego siebie za tych, których dał Mu Ojciec (J 17, 19). Szczególnie jednak jego kres, a więc męka i śmierć na krzyżu, stanowią objawienie miłości względem grzeszników, która właśnie teraz dochodzi do szczytu: „Umiłowawszy swoich, którzy byli na świecie, do końca ich umiłował" (J 13, 1). Z miłości Ojciec wydaje dla nas to, co najdroższe, a więc swojego Syna. Syn natomiast z miłości wstępuje w najgłębszą ciemność świata, w śmierć i piekło, biorąc na siebie winę wszystkich swoich braci. W śmierci Chrystusa na krzyżu jaśnieje bezgraniczna, poświęcająca się miłość i dobroć Boga chwały, wspaniałego i wielkodusznego w swej miłości. Jest to nade wszystko miłość Ojca, który zezwala Synowi na zaangażowanie się w dzieło odkupienia aż po złożenie na krzyżu całkowitej ofiary z siebie. Miłość ta w wydarzeniu krzyża okazuje się silniejszą od wszystkich potęg świata (Rz 8, 32-39). Jest to zarazem miłość Syna, który w posłuszeństwie aż do śmierci na krzyżu wypełnia wolę Ojca (Hbr 10, 7), utożsamiając się z grzesznikami. Wspaniałość miłości Boga promieniuje z krzyża, któremu nic nie może odebrać znaczenia, ani też go udaremnićc ${ }^{30}$.

Bazylejski teolog podkreśla, że tak ekstremalna, ukrzyżowana miłość jest dla oczu świata czymś absolutnie nieprzezwidywalnym, manifestując nieuchwytność przenikającej ją boskiej chwały. Św. Jan poświadcza, że ucieleśniona w Jezusie Chrystusie miłość Boga jaśnieje blaskiem chwały nawet w stanie skrajnej kenozy. W konfrontacji z ciemnością i nienawiścią światło chwały jaśnieje ze szczególną intensywnością. W śmierci na krzyżu staje się możliwe wyrażenie do samego końca miłości Boga, która przewyższa wszelką wiedzę (Ef 3, 19). Słowo, które zamilkło, nabywa absolutnej

29 TD II/1, 75-76; TD IV, 458.

${ }^{30}$ H III/2/2, 190-192; MP, 139; H I, 226; por. H. U. von Balthasar, Das betrachtende Gebet, Einsiedeln 1976, 162-163; tenże, Klarstellungen, Einsiedeln 1978, 37. Por. L. Scheffczyk, "Satisfactio non efficax nisi ex caritate». Zur Frage nach dem Grund der Erlösung in Tod und Auferstehung Christi, "Annales Theologici" 1 (1987)1/2, 73-94. 
transparencji sprawiając, że Bóg właśnie w tajemnicy krzyża może wyrazić siebie jak nigdy dotąd. W krzyżu jaśnieje prawdziwa, niedościgniona, wykraczająca ponad ludzkie wyobrażenia chwała Bożej miłości, ale przez to też ewidentnie oczywista jako miłość. Właśnie w śmierci w sposób najbardziej ewidentny objawia się prawda, że miłość jest rzeczywiście miłością i niczym innym, jak tylko miłością ${ }^{31}$. Stąd też Balthasar pisze:

Wiarygodna jest tylko miłość; trzeba i można wierzyć nie czemu innemu, jak tylko miłości... Wiara, że istnieje miłość, absolutna miłość - i to jako ostateczność, poza którą nie ma już nic... Pierwsze, co musiałoby się rzucać w oczy niechrześcijanom w wierze chrześcijan, to fakt, że ci ostatni mają najwyraźniej i jawnie za dużą odwagę. To zbyt piękne, by mogło być prawdziwe: misterium bytu odsłania się jako absolutna miłość, która zstępując obmywa stworzeniu nogi, więcej, dusze, i bierze w siebie wszelkie brudy grzechu, wszelką nienawiść przeciwko Bogu, wszystkie brutalne oskarżenia zrzucane na Niego, wszelką niewiarę zakrywającą szyderczo na powrót Jego odsłonięcie się, wszelkie zatwardziałe lekceważenie Jego niepojętego zstąpienia, a to wszystko po to, aby usprawiedliwić przed sobą i przed światem swoje stworzenie. To rzeczywiście za wiele dobra. Nic na świecie nie usprawiedliwia takiej metafizyki..., przekroczenie wszelkich granic rozsądku. Ale wtedy pozostajemy w kręgu «mądrości» i tak uciekamy znowu przed absolutnym znakiem zgorszenia krzyża ${ }^{32}$.

Krzyż jest wywyższeniem i szczytową gloryfikacją trynitarnej miłości w jej radykalnej inności. Potrzeba jednak oczu wiary, by dostrzec chwałę na obliczu Ukrzyżowanego.

\section{IL MISTERO DELLA CROCE NEL PENSIERO DI HANS URS VON BALTHASAR}

\section{RIASSUNTO}

Il nostro articolo segue il pensiero cristologico di Hans Urs von Balthasar nella sua originale struttura trilogica. Il teologo di Basilea presenta il mistero del

${ }^{31} \mathrm{H}$ III/2/2, 66.78.190.195-196.263-265.327.426-427.508; GL, 57.62.96. Por. W. Tinnefeldt, Ekstasis der Liebe und Entfaltung des Glaubens. Eine Untersuchung zur Frage nach der Mitte und Einheit der christlichen Wahrheit bei Hans Urs von Balthasar, Mainz 1975.

${ }^{32}$ GL, 67-68. 
Dio-Uomo in tre diverse prospettive, conformemente ai tre trascendentali: bellezza, bontà e verità, strettamente legati tra loro. Ogni tentativo di separare uno di loro dagli altri fa che il pensiero cristologico di Balthasar diventa incomprensibile sia nella sua totalità, che nei dettagli. Questa originale scelta, che gli dà la possibilità di distanziarsi dalle fredde e troppo schematiche speculazioni teoretiche della vecchia scuola cristologica - sempre piů lontana dalle fonti rivelate e rimasta sotto l'influsso della neoscolastica - gli consente di creare una cristologia vista come viva, dinamica e impegnante testimonianza data a Cristo e alla sua opera salvifica. Conformemente a questa fondamentale visione, nella nostra ricerca viene presentato il mistero della croce: la potenza di Dio rivelata nel dramma della croce - riflessione concentrata sulla bontà: (p. 1), la sapienza della croce - stoltezza per i pagani - che ha come fulcro la verità: (p. 2), concludendo con la visione della gloria di Dio nella croce scandalo per i giudei - costruita intorno alla bellezza: (p. 3). 